\title{
Editorial
}

\section{Papel da praia na proteção da costa: respostas morfodinâmicas em diferentes escalas espaciais}

Ao longo da evolução costeira, a praia desempenha o importante papel de proteger a costa contra a ação das ondas ao ajustar sua morfologia ao balanço sedimentar e energético do sistema litorâneo.

A variabilidade de uma praia está associada à sua própria gênese, pois sua configuração surge como resultado da interação da dinâmica atuante (ondas, correntes e marés), dos contornos existentes (forma da costa e batimetria da plataforma continental interna), presença de recifes (arenitos, algálicos e de corais) e a disponibilidade de sedimentos no sistema. Assim, a praia tende a se ajustar às forçantes, gerando grande variabilidade, principalmente se considerarmos a costa brasileira, onde ocorre grande diversidade de processos.

Atualmente, um dos grandes desafios da gestão costeira é compatibilizar o ordenamento territorial com a intensa pressão imobiliária, bem como com os processos naturais, de modo a que a utilização dessas áreas, especialmente a praia, seja efetuada de forma harmoniosa e sustentável, com o objetivo de preservar suas potencialidades nos diversos cenários de mudanças climáticas e variação do nível do mar.

A proposta desse eixo temático especial Papel das praias na proteção da costa: respostas morfodinâmicas em diferentes escalas espaciais, publicado em dois volumes, é contribuir para o entendimento do comportamento morfodinâmico das praias ao longo do litoral brasileiro, e assim auxiliar no gerenciamento desse espaço tão sensível, garantindo e preservando os mesmos para as futuras gerações.

Agradecemos ao Editor Chefe pelo convite e oportunidade honrosa de editarmos esse volume especial, agradecemos aos autores que acreditaram no projeto e desejamos à comunidade costeira da ABEQUA, uma boa leitura! 